\title{
Five new species and one new genus of recent miliolid foraminifera from Raja Ampat (West Papua, Indonesia)
}

Meena Förderer, Martin R Langer

Raja Ampat is an archipelago with about 1500 small islands located northwest off the Bird's Head Peninsula of Indonesia's West Papua Province. It is part of the Coral Triangle, a region recognized as the "epicenter" of tropical marine biodiversity. In the course of a large-scale survey on shallow benthic foraminifera we have discovered one new genus and five new species of recent miliolid benthic foraminifera from the highly diverse reefal and nearshore environments. The new fischerinid genus Dentoplanispirinella is characterized by its planispiral coiling and the presence of a simple tooth, that differentiates it from Planispirinella Wiesner. It is represented in our sample material by the new species Dentoplanispirinella occulta. The other four species described herein are Miliolinella moia, Miliolinella undina, Triloculina kawea and Siphonaperta hallocki. All new species are comparatively rare and occur sporadically in the sample material. Detailed morphological descriptions, scanning electron microscopy pictures of complete and dissected specimens as well as micro-computed tomography images are provided. 
1 Five new species and one new genus of recent miliolid

2 foraminifera from Raja Ampat (West Papua, Indonesia)

3 Meena Förderer, Martin R. Langer

4 Department of Paleontology, Steinmann Institute, University of Bonn, Bonn, Germany

5 Corresponding Author:

6 Martin R. Langer

7 Nussallee 8, Bonn, 53115, Germany

8 Email address: martin.langer@uni-bonn.de

9 


\begin{abstract}
Raja Ampat is an archipelago of about 1500 small islands located northwest off the Bird's Head Peninsula of Indonesia's West Papua Province. It is part of the Coral Triangle, a region recognized as the "epicenter" of tropical marine biodiversity. In the course of a large-scale survey on shallow benthic foraminifera we have discovered one new genus and five new species of recent miliolid benthic foraminifera from the highly diverse reefal and nearshore environments. The new fischerinid genus Dentoplanispirinella is characterized by its planispiral coiling and by the presence of a simple tooth, that differentiate it from Planispirinella Wiesner. It is represented in our sample material by the new species Dentoplanispirinella occulta. The other four species described herein are Miliolinella moia, Miliolinella undina, Triloculina kawea and Siphonaperta hallocki. All new species are comparatively rare and occur sporadically in the sample material. Detailed morphological descriptions, scanning electron microscopy pictures of complete and dissected specimens as well as micro-computed tomography images are provided.
\end{abstract}

\title{
Introduction
}

The Raja Ampat Archipelago (West Papua, Indonesia) off the northwestern coast of New Guineas Bird's Head Peninsula (Fig. 1B) is one of the most species rich marine environments (Erdmann \& Pet, 2002; McKenna, Allen \& Suryadi, 2002), situated in the Indo-Pacific's "epicenter" of biodiversity, commonly referred to as the Coral Triangle (Hoeksema, 2007). The Coral Triangle encompasses a large part of the tropical marine waters of Indonesia, the Philippines, Malaysia, the Solomon Islands, Papua New Guinea and Timor-Leste (Fig. 1A). It includes ecoregions that are each home to at least 500 species of hermatypic corals and also show extraordinary diversity among coral associated species (Veron, 1995; Veron et al., 2009; Roberts et al., 2002; Bellwood \& Hughes, 2001; Tittensor et al., 2010). The region is recognized as a "species factory" and functions as the most significant net exporter of biodiversity for adjacent reef regions (Briggs \& Bowen, 2013; Ekman, 1953).

Comprehensive studies on benthic foraminifera from the central Indo-Pacific region began with marine scientific expeditions in the late 1800s with the report on the Challenger Foraminifera by Brady (1884), and the work of Millett (1898-1904) from the Malay Archipelago. In the $20^{\text {th }}$ century, systematic surveys were conducted around the Philippines (Cushman, 1921; Graham \& Militante, 1959), in the Papuan Lagoon near Port Moresby, Papua New Guinea (Haig, 1988a; Haig, 1988b; Haig, 1993), in the Timor Sea and Sahul Shelf (Loeblich \& Tappan, 1994), in Madang, eastern Papua New Guinea (Langer, 1992; Langer \& Lipps, 2003) and more recently in the Ningaloo Reef area at Australia's northwest coast (Parker, 2009), at Chuuk Island of the Caroline reefs (Makled \& Langer, 2011) and around New Caledonia (Debenay, 2012). Recent environmental and biogeographic studies on larger benthic foraminifera in the tropical waters of the central Indo-Pacific were conducted by Langer and Hottinger (2000), Renema (2003; 2005; 2006; 2010), Renema \& Troelstra (2001), Hohenegger (2004; 2005; 2011), Weinmann et al. (2013), and Prazeres, Uthicke \& Pandolfini (2016).

To date, however, large-scale systematic studies on benthic foraminifera from Raja Ampat are lacking. The archipelago consists of the four main islands Waigeo, Batana, Salawati, and Misool, and hundreds of small satellite islets, which are largely uninhabited. Due to its remote location and difficult access conditions the coral reefs of the region remained relatively unexplored and pristine. However, increasing exposure to exploitation have required the establishment of several marine protected areas (Agostini et al., 2012). The first and to date only report on benthic foraminifera from Raja Ampat is that 
62

63

64

65

66

67

68

69

70

71

72

73

74

75

76

77

78

79

80

81

82

83

84

85

86

87

88

89

90

91

92

93

94

95

96

97

98

99

100

101

102

103

104

105 of Hofker $(1927 ; 1930)$, who examined the material taken by the Siboga Expedition (1899-1900) that included five samples from Raja Ampat. He documented nine species of benthic foraminifera including eight rotalid taxa and the miliolid symbiont bearing species Peneroplis pertusus (Forskål).

\section{Material and Methods}

This study was conducted with 30 sediment samples from the Raja Ampat Archipelago (New Guinea, Indonesia) from around the islands of Waigeo, Batana, Kawe, Fam and adjacent small islets in an area that covers about $2,500 \mathrm{~km}^{2}$ (Fig. 1C). The archipelago is located in the central Indo-Pacific warm pool with an average annual sea surface temperature of $29^{\circ} \mathrm{C}$ (Mangubhai et al., 2012). Raja Ampat is further situated in the passage way of the Indonesian Throughflow, a major ocean current that leads water masses from the western Pacific to the eastern Indian Ocean. Previous studies have shown that the reef fauna of Raja Ampat is strongly current dependent (DeVantier, Turak \& Allen, 2009; Turak, 2003).

The samples were collected by snorkeling and SCUBA diving in September 2011 by M. Langer. Sediment surface samples from the top $2 \mathrm{~cm}$ were collected from the fore-reef slope of fringing reefs, with two samples from a patch reef, and two samples from a sandy channel with sparse coral cover (Tbl. 1). The sediment was predominantly carbonaceous ( $90 \%$ ) and included fine-grained sediments as well as coarse reef rubble. All samples were washed through a $63 \mu \mathrm{m}$ sieve and dried at $50^{\circ} \mathrm{C}$ in an oven overnight. Foraminifera were picked from each sample and the best preserved specimens were imaged using a Tescan VEGA MV2300 Scanning Electron Microscope (SEM) at the Steinmann Institute of the University of Bonn. Digital plates were assembled using Adobe Photoshop CS6. Micro-computer tomography (CT) scan imaging was conducted using a phoenix $v \mid$ tome $\mid x$ s computed tomography system at the Steinmann Institute and visualization was carried out with Avizo 7.1.0. The new species and the new genus are described in detail using the supra-generic classification of Loeblich \& Tappan (1987).

Repository of the Material: The holotypes and topotypic paratypes of the new species are deposited in the micropaleontology collection of the Steinmann Institute of Paleontology at the University of Bonn, Germany (MaLaPNG 2011-10, MaLaPNG 2011-11, MaLaPNG 2011-12, MaLaPNG 2011-13, MaLaPNG 2011-14).

The electronic version of this article in Portable Document Format (PDF) will represent a published work according to the International Commission on Zoological Nomenclature (ICZN), and hence the new names contained in the electronic version are effectively published under that Code from the electronic edition alone. This published work and the nomenclatural acts it contains have been registered in ZooBank, the online registration system for the ICZN. The ZooBank LSIDs (Life Science Identifiers) can be resolved and the associated information viewed through any standard web browser by appending the LSID to the prefix http://zoobank.org/. The LSID for this publication is:

urn:Isid:zoobank.org:pub:FB001C3C-AEA9-45D5-9224-EDD084378897. The online version of this work is archived and available from the following digital repositories: PeerJ, PubMed Central and CLOCKSS.

\section{Results}

Smaller miliolid benthic foraminifera are typical dwellers in surface sediments of shallow water reefal and lagoonal habitats. By studying the highly diverse assemblages of benthic foraminifera from Raja 
106

107

108

109

110

111

112

113

114

115

116

117

118

119

120

121

122

123

124

125

126

127

128

129

130

131

132

133

134

135

136

137

138

139

140

141

142

143

144

145

146

147

148

149

150

151

152

153

Ampat, taken from different locations around the islands (Fig. 1C), we recorded a total of 455 species among them 249 miliolid species, of which five are described here as new. Four species belong to the widely distributed miliolid genera of Miliolinella Wiesner, Triloculina d'Orbigny and Siphonaperta Vella. As the morphological properties of the fifth species differentiate it from any previously known genera, we designate and describe it as the new genus Dentoplanispirinella.

\section{Systematic descriptions}

Subclass Miliolana Saidova 1981

Order Miliolida Delage \& Hérouard 1896

Suborder Miliolina Delage \& Hérouard 1896

Superfamily Cornuspiracea Schultze 1854

Family Fischerinidae Millett 1898

Subfamily Fischerininae Millett 1898

Genus Dentoplanispirinella Förderer and Langer gen. nov.

urn:Isid:zoobank.org:act:98A1DD41-COAE-4401-830B-0D189E70661A

Description. Test small, broadly circular in outline, discoidal to slightly biconvex. Periphery with a weakly developed subrounded keel that encircles the entire test margin. Wall thick, calcareous, porcelaneous, imperforate. Coiling involute, throughout planispirally enrolled with 2.5 to 3.5 tubular chambers per whorl, each whorl slightly offset to the proceeding coil with a tendency to become sigmoiline (axial section as seen in $\mathrm{CT}$ scan, Fig. $2 \mathrm{H}$ ). Lateral wall extensions of the adult chambers entirely cover the earliest chambers and tend to overlap the umbilical region in each whorl. Sutures oblique, thin and irregular. Aperture arch-shaped, triangular in juvenile specimens, high and subtriangular in adult specimens, tapering apically, on the base connected with the peripheral margin of the proceeding chamber and provided with a very small and thin tooth. In juvenile specimens the tooth appears just like a little knob or slightly raised spine.

Type species. Dentoplanispirinella occulta sp. nov.

Remarks. Dentoplanispirinella gen. nov. resembles Planispirinella Wiesner 1931 in having a discoidal shape, a high aperture and a planispiral chamber arrangement, but differs from Planispirinella by the presence of a tooth and the more biconvex test shape in apical view (Fig. 2B). The apertural features and the coiling mode of Dentoplanispirinella further distinguish it from Nummoloculina Steinmann 1881, which has an apertural flap and an early quinqueloculine coiling.

Dentoplanispirinella occulta Förderer and Langer sp. nov.

Figure 2A-K urn:Isid:zoobank.org:act:7E132939-5284-484D-9B50-BC79A0B52D0A

Etymology. From the Latin "occultare" meaning for "hiding".

Material. 28 specimens from nine samples (MR18, MI05, MI06, MS03, MS04, MG, M21, U16, Y24; Fig. 1C; Tbl. 1), recent.

Holotype. The specimen illustrated here as Fig. 2C, D (sample MS03; MaLaPNG 2011-10). 
154

155

156

157

158

159

160

161

162

163

164

165

166

167

168

169

170

171

172

173

174

175

176

177

178

179

180

181

182

183

184

185

186

187

188

189

190

191

192

193

194

195

196

197

198

199

200

201

Paratype. The specimen illustrated here as Fig. 2A, B (sample MS03; MaLaPNG 2011-10).

Type locality. The holotype and the paratype are from sample station MSO3 $(16 \mathrm{~m})$, a sand channel between Arborek Island and Pulau Mansuar; Raja Ampat, New Guinea (Indonesia).

Diagnosis. A species of Dentoplanispirinella gen. nov. with a discoidal to biconvex test shape, a slightly keeled periphery, a radial oriented, finely striate surface ornamentation and an arch-shaped, triangular aperture, provided with a small tooth.

Dimensions. Observed range of test dimensions: diameter 285 - $704 \mu \mathrm{m}$ (lateral view), test width 100 $193 \mu \mathrm{m}$ (apertural view).

Occurence. Dentoplanispirinella occulta is widely distributed in the Raja Ampat area in fine to coarse coral rubble samples from depths of 14 to 45 meters.

Description. Test porcelaneous and imperforate. Almost circular in lateral view, lenticular and biconvex in apertural view with a slightly developed, subrounded keel and weakly inflated chambers. Coiling planispiral and involute. Two and a half to three and a half chambers visible from the exterior. Lateral wall extensions of the adult chambers entirely cover the earliest chambers and tend to overlap the umbilical region; the final chamber covers approximately half of the test surface. Sutures oblique, thin, irregular and recurved near the periphery. Test surface ornamented with radial oriented, fine, subparallel to anastomosing striae that are straight to slightly curved backwards, towards the outer margins of the chambers. Umbilical region and test periphery more weakly ornamented. Outer wall layer constructed of longitudinally aligned needle-shape crystals, oriented perpendicular to direction of ornamentation. The test appears matte white under the light microscope with a slightly translucent periphery. Apertural face not ornamented. Aperture arch-shaped and triangular in juvenile specimens, high and subtriangular in adult specimens, tapering apically, on the base connected with the peripheral margin to the preceding chamber and provided with a peristomal rim. Aperture provided with a very small and thin tooth, with the flat side oriented in lateral direction.

Remarks. Dentoplanispirinella occulta sp. nov. differs from Planispirinella involuta Collins (1958, p. 374, pl. 4, figs $2 \mathrm{a}, \mathrm{b}$ ) by its more lenticular biconvex shape in horizontal section, the subtriangular shape of the aperture, the presence of a small tooth, and the striate surface ornamentation.

Superfamily Miliolacea Ehrenberg 1839

Family Hauerinidae Schwager 1876

Subfamily Hauerininae Schwager 1876

Genus Miliolinella Wiesner 1931

Miliolinella moia Förderer and Langer sp. nov.

Figure 3A-L

urn:Isid:zoobank.org:act:D8184E0C-2805-40D7-BCCB-492D74216168

Etymology. The new species is named after the indigeneous Moi people from Malaumkarta, a Papuan tribe from the north coast near Sorong. 
202

203

204

205

206

207

208

209

210

211

212

213

214

215

216

217

218

219

220

221

222

223

224

225

226

227

228

229

230

231

232

233

234

235

236

237

238

239

240

241

242

243

244

245

246

247

248

249
Material. 11 specimens from six samples (B14, B15, E23, MR17, N18, U16; Fig. 1C; Tbl. 1), recent.

Holotype. The specimen illustrated here as Fig. 3A-C (sample B14; MaLaPNG 2011-11).

Paratypes. The specimens illustrated here as Fig. 3D-F (sample B14), Fig. 3G-I and Fig. 3J-L (sample ER23; MaLaPNG 2011-11).

Type locality. The holotype and the paratype are from sample station B14 (41m), Bag Island, east of Pulau Uranie; Raja Ampat, New Guinea (Indonesia).

Diagnosis. A slightly enlongated, medium-sized species of Miliolinella Wiesner 1931 with a compressed, angular and slightly slanted outline, a smooth and shiny wall, and a high subcircular opening.

Dimensions. Observed range of test dimensions: test height 409 - $554 \mu \mathrm{m}$, test width 278 - $396 \mu \mathrm{m}$ (lateral view), 166 - $250 \mu \mathrm{m}$ (apertural view).

Occurence. This species is widely distributed in the Raja Ampat area in fine to coarse coral rubble samples and occurs at depths between 12 and 45 meters.

Description. Test porcelaneous and imperforate, ovate in outline and slightly higher than broad. Test weakly compressed and flattened, subtriangular in apertural view. Chamber arrangement quinqueloculine with five chambers visible from the exterior. In some specimens only three to four chambers are visible. Periphery rounded to subrounded, chambers slightly inflated. Sutures curved, distinct and weakly depressed. Chambers tend to be off-centered, giving them a slanted appearance. Test wall smooth, translucent to opaque and glossy under the light microscope. Aboral end of the chambers slightly constricted. Aperture in basal position, a Miliolinella-type large subcircular opening with an everted peristomal rim and a semicircular, slightly excavated flap, that covers more than half of the opening.

Remarks. Miliolinella moia sp. nov. differs from Miliolinella pilasensis McCulloch 1977 (p. 566, pl. 238, fig. 16 and Loeblich \& Tappan 1994, p. 57, pl. 99, figs 1-9) in its angular and more compressed outline, and the large subcircular opening. Millet (1898) depicted a species of Miliolina valvularis (Reuss) from the Malay Archipelago (p. 11, fig. 5a-c) that shows a high degree of similarity to Miliolinella moia, but his specimen has a more rounded periphery. The original description of Triloculina valvularis by Reuss (1851, p. 85, pl. 7, fig. 56) shows a specimen with a broadly rounded periphery and inflated chambers without angles. Miliolinella sp. 2 figured in Parker 2009 from Ningaloo Reef, Australia (p. 128, figs 92a-i, 93a-j, 94a-k) differs from Miliolinella moia by the low apertural opening and the broadly rounded and more inflated chambers.

Miliolinella undina Förderer and Langer sp. nov.

Figure 4A-I

urn:Isid:zoobank.org:act:D11E1426-9DCC-41B8-A992-27D974A92520

1988a Miliolinella sp. B - Haig, Papuan Lagoon, Port Moresby, p. 224, pl. 2, figs 23, 24.

1992 Miliolinella sp. - Hatta \& Ujiié, Ryukyu Islands, p. 72, pl. 10, fig. 6.

?2012 Miliolinella cf. M. semicostata (Wiesner) - Debenay, New Caledonia, p. 110, 275. 
250

Etymology. After the undulate ornamentation of the test. From the Latin "unda" meaning wave and mythological "Undine", a term established by the Renaissance alchemist Paracelcus for water spirits.

Material. Three specimens from three samples (MR18, N18, U16; Fig. 1C; Tbl. 1), recent.

Holotype. The specimen illustrated here as Fig. 4A-C (sample MR18; MaLaPNG 2011-12).

Paratypes. The specimens illustrated here as Fig. 4D-F (sample N18) and Fig. 4G-I (sample U16; MaLaPNG 2011-12).

Type locality. The holotype is from sample station MR18 $(18 \mathrm{~m})$, east of Kawe Island. The paratypes are from sample stations N18 (30m), south-west coast of Pulau Wayag, and U16 (45m), between Pulau Uranie and Bag Island; Raja Ampat, New Guinea (Indonesia).

Diagnosis. A small quinqueloculine species of Miliolinella Wiesner with inflated chambers, a rounded outline and an undulate to reticulate surface ornamentation.

Description. Test porcelaneous and imperforate, small, ratio of height and width variable but usually slightly higher than broad. Periphery rounded and chambers slightly inflated. Chamber arrangement quinqueloculine, with five chambers visible from the exterior. Aboral end rounded, flush with the surface in the holotype to slightly raised in paratypes. Wall smoothly finished, matte, translucent under the light microscope. Sutures curved and depressed. Test surface ornamented with numerous irregular, predominantly longitudinal, somehow honeycombed reticulate to undulate low anastomosing costae that are covering large parts of the test. Outer-wall layer constructed of needle-shaped crystals that are primarily aligned in longitudinal direction. Aperture basal, a large semicircular Miliolinella-type opening, provided with a thickened and everted peristomal rim and a broad, slightly excavated basal flap.

Dimensions. Observed range of test dimensions: test height 146 - $162 \mu \mathrm{m}$, test width 114 - $224 \mu \mathrm{m}$ (lateral view), 81 - $119 \mu \mathrm{m}$ (apertural view).

Occurence. Miliolinella undina is present with one specimen in each of three highly diverse, miliolid-rich, fine coral rubble samples from depths of 18 to 45 meters.

Remarks. Specimens of Miliolinella undina sp. nov. have been previously documented by Haig 1988a as Miliolinella sp. B from the Papuan Lagoon, Port Moresby and by Hatta \& Ujiie 1992 as Miliolinella sp. from the Ryukyus. Hatta \& Ujiié mentioned the species to occur rarely in their assemblages. The new species has also been recorded in samples from northern Palawan (Philippines, Förderer unpubl. data). Miliolinella cf. M. semicostata (Wiesner) depicted by Debenay from New Caledonia (2012, p. 110, 275) may also belong to Miliolinella undina, but shows a less undulated test ornamentation. Test shape, apertural and ornamental features are more similar to our holotype (Fig. 4A-C) than to Miliolinella semicostata (Wiesner 1923) from the Mediterranean Sea (see Cimerman \& Langer 1991, p. 42, pl. 38, figs 10-15). Miliolinella semicostata has less inflated chambers and the ornamentation is not reticulate but longitudinally striate and restricted to the angles. Miliolinella undina also resembles Miliolinella sp. 4 depicted by Parker from the Ningaloo Reef in Western Australia (2009, p. 136, fig. 97a-h), but his specimen has a less undulated and more striate alignment of costae. The new species also resembles Miliolinella flintiana (Cushman) (1932, p. 55, pl. 12: 4a-c) in size, test shape, chamber arrangement and apertural features. However it differs in its surface ornamentation, that is distinctly longitudinal costate 
301

302

303

304

305

306

307

308

309

310

311

312

313

314

315

316

317

318

319

320

321

322

323

324

325

326

327

328

329

330

331

332

333

334

335

336

337

338

339

340

341

342

343

344

345

in Miliolinella flintiana and undulate and more irregular in Miliolinella undina. Miliolinella flintiana also occurs in our assemblages.

Genus Triloculina d'Orbigny 1826

Triloculina kawea Förderer and Langer sp. nov.

Figure $5 \mathrm{~A}-\mathrm{H}$

urn:Isid:zoobank.org:act:6F5B38CE-88B3-4FBE-9329-8483756158E1

2009 Triloculina? sp. 2 - Parker, Ningaloo Reef, p. 372, fig. 271f-j.

Etymology. This species is named in honor of the indigeneous people of West Papua after the Kawe tribe, that owns and protects a highly diverse Marine Protected Area of Raja Ampat.

Material. 12 specimens from seven samples (B15, FW, M05, MS04, N18, U16, Y25; Fig. 1C; Tbl. 1), recent.

Holotype. The specimen illustrated here as Fig. 5A-C (sample FW; MaLaPNG 2011-13).

Paratype. The specimen illustrated here as Fig. 5E-G (sample FW; MaLaPNG 2011-13).

Type locality. The holotype and the paratype are from sample station FW $(49 \mathrm{~m})$, south-east Penemu, Fam Islands; Raja Ampat, New Guinea (Indonesia).

Diagnosis. A medium-sized species of Triloculina d'Orbigny with a slightly elevated "Lachlanella"-type aperture, rounded periphery, blunt angles and a roughly textured wall.

Dimensions. Observed range of test dimensions: test height 377 - $439 \mu \mathrm{m}$, test width $200-245 \mu \mathrm{m}$ (lateral view), 162 - $195 \mu \mathrm{m}$ (apertural view).

Occurence. This species is widely distributed in our sampling area in fine to coarse coral rubble samples from depths of 14 to 49 meters.

Description. Test porcelaneous and imperforate, about one and a half times longer than broad. Broadly triangular in apertural view, ovate in outline. Chamber arrangement triloculine, periphery rounded to subrounded, chambers inflated with blunt angles. Sutures distinct and depressed. Surface ornamented with elongated, irregular longitudinal arranged short striae covering the entire test surface, giving the appearance of a matte and roughly textured wall under the light microscope. Outer wall layer consisting of longitudinally aligned plate shaped crystals. Aboral end rounded and slightly produced, oral end produced and connected with the peripheral margin of the preceeding chamber. Aperture basal, "Lachlanella"-type with a long slender tooth that becomes thickened at the tip.

Remarks. The species Triloculina? sp. 2 reported by Parker 2009 from Western Australia differs from Triloculina kawea sp. nov. in its less triangular shape and less elongated outline. We consider Parker's specimen a juvenile individual of Triloculina kawea. The aperture of Parker's specimen is not intact but resembles very well the apertural features of Triloculina kawea. The outer wall layer appears identical (Fig. 5H). Parker mentioned the species to be possibly cryptoquinqueloculine. Figures 5B, F and the 
horizontal section (5D) show the triloculine chamber arrangement. Triloculina sp. 1, reported by Debenay 2012 from New Caledonia (p. 139, 278) is very similar in shape and surface ornamentation to Triloculina kawea, but has significantly more acute angles and a Y-shaped tooth. Triloculina kawea further differs from Triloculina linneiana d'Orbigny depicted by Baccaert 1987 from the Great Barrier Reef (p. 128, pl. 57, figs 3,4 ) in the less striate ornamentation and more acute angles.

\section{Subfamily Siphonapertinae Saidova 1975}

Genus Siphonaperta Vella 1957

Siphonaperta hallocki Förderer and Langer sp. nov.

Figure 6A-F

urn:Isid:zoobank.org:act:DD4F0DB3-1355-4BB1-841A-FFE32E0F6455

?1988a Quinqueloculina sp. C - Haig, Papuan Lagoon, Port Moresby, p. 234, pl. 9, figs 7-10. ?2009 Quinqueloculina sp. 13 - Parker, Ningaloo Reef, p. 311, figs 224a-j, 225a-g.

Etymology. In honor of Pamela Hallock Muller for her extensive work on tropical foraminifera.

Material. Four specimens from three samples (MS03, N18, W07; Fig. 1C; Tbl. 1), recent.

Holotype. The specimen illustrated here as Fig. 6A-C (sample MS03; MaLaPNG 2011-14).

Paratype. The specimen illustrated here as Fig. 6D-F (sample N18; MaLaPNG 2011-14).

Type locality. The holotype is from sample station MSO3 $(18 \mathrm{~m})$, a sand channel between Arborek Island and Pulau Mansuar. The paratype is from sample station N18 $(30 \mathrm{~m})$, south-west coast of Pulau Wayag; Raja Ampat, New Guinea (Indonesia).

Diagnosis. A medium-sized species of Siphonaperta Vella with a finely agglutinated wall, carinate shoulders, a short neck and a circular aperture with a small bifid tooth.

Description. Test porcelaneous and imperforate, medium-sized, about two times longer than broad, and ovate in outline. Outer layer of the calcareous test wall covered with finely agglutinated mostly biogenic grains. Agglutinated grains are particularly frequent along the sutures. Periphery carinate to subacute. Chamber arrangement quinqueloculine with five chambers visible from the exterior. Sutures slightly curved, incised and depressed. Chambers weakly inflated and angular in section, with weakly developed longitudinal striae (in well preserved specimens). Aboral end rounded and produced; oral end becoming more slender and leading into a short produced neck. Aperture terminal, a wide circular opening with a short T-shaped, bifid tooth, that reaches more than one third of the apertural diameter. Apertural opening surrounded by a slightly thickened and everted peristomal rim.

Dimensions. Observed range of test dimensions: test height $240-442 \mu \mathrm{m}$, test width $132-233 \mu \mathrm{m}$ (lateral view), 87 - $119 \mu \mathrm{m}$ (apertural view).

Occurence. Siphonaperta hallocki occurs sporadically in fine to coarse coral rubble samples from depths of 16 to 30 meters. 
394

395

396

397

398

399

400

401

402

403

404

405

406

407

408

409

410

411

412

413

414

415

416

417

418

419

420

421

422

423

424

425

426

427

428

429

430

431

432

433

434

435

436

437

438

439

440

441
Remarks. Very similar specimens were previously documented as Quinqueloculina sp. C from the Papuan Lagoon (Haig, 1988a) and Quinqueloculina sp. 13 from Ningaloo Reef (Parker, 2009). Test shape, wall texture and apertural features appear to be identical to our specimens from Raja Ampat.

Quinqueloculina sp. 4 documented by Parker 2009 from the Ningaloo Reef appears very similar to Siphonaperta hallocki, but differs in its more elongated shape, more rounded and inflated chambers and the cryptoquinqueloculine coiling. In addition, Parker describes the wall as roughly textured with some agglutinated grains. Quinqueloculina tropicalis Cushman from Samoa (1924, p. 63, pl. 23, figs 9, 10) differs from our new species by its more compressed shape and more elongated broadly rounded chambers without any angles or costae. Quinqueloculina polygona d'Orbigny (1839, p. 198, pl. 12, figs 21-23) differs from Siphonaperta hallocki in its smooth and shiny surface, the pronounced carinae and the less inflated chambers. Langer et al. 2013 depicted a specimen of Quinqueloculina polygona d'Orbigny from Bazaruto (Langer et al., 2013, p. 163, fig. 5: 14) that resembles our new species in size, shape and apertural features. However, it is unlikely that this species from Bazaruto belongs to Siphonaperta hallocki, as its outer wall layer is not agglutinated.

\section{Acknowledgements}

The authors gratefully acknowledge Dr. Stefanie Pietsch for assistance with the collection of the samples, Georg Oleschinski for help with the SEM and Peter Göddertz and Kai Jäger for support with CT scan imaging. We thank Justin H. Parker, Tomas Cedhagen and an anonymous reviewer for constructive and helpful comments on the manuscript.

\section{References}

Agostini VN, Grantham HS, Wilson J, Mangubhai S, Rotinsulu C, Hidayat N, Muljadi A, Muhajir, Mongdong M, Darmawan A, Rumetna L, Erdmann MV, Possingham HP. 2012. Achieving Fisheries and Conservation Objectives within Marine Protected Areas: Zoning the Raja Ampat Network. The Nature Conservancy, Indo-Pacific Division, Denpasar. Report No 2/12. Available at https://www.conservationgateway.org/Documents/Agostini\%20etal12_Raja\%20Ampat\%20Zoning\%20R EPORT.pdf (accessed 24 February 2016)

Baccaert J. 1987. Distribution patterns an taxonomy of benthic foraminifera in the Lizard Island Reef Complex, northern Great Barrier Reef, Australia. Ph.D. thesis, Université de Liège.

Bellwood DR, Hughes TP. 2001. Regional-Scale Assembly Rules and Biodiversity of Coral Reefs. Science 292:1532-1534. DOI: 10.1126/science.1058635.

Brady HB. 1884. Report on the Foraminifera dredged by H. M. S. Challenger during the years 1873-1876. Reports of the Scientific Results of the Voyage of H. M. S. Challenger, Zoology, 9:1-814.

Briggs JC, Bowen BW. 2013. Marine shelf habitat: biogeography and evolution. Journal of Biogeography 40:1023-1035. DOI:10.1111/jbi.12082.

Cimerman F, Langer MR. 1991. Mediterranean Foraminifera. Ljubljana: Slovenska akademija znanosti in umetnosti. Academia Scientiarum et Artium Slovencia Classis IV: Historia Naturalis. 
442 Collins AC. 1958. Foraminifera. In: Great Barrier Reef Expedition 1928-1929. British Museum of Natural 443 History, Scientific Reports 6:335-437.

444

445

446

447

448

449

450

451

452

453

454

455

456

457

458

459

460

461

462

463

464

465

466

467

468

469

470

471

472

473

474

475

476

477

478

479

480

481

482

483

484

485

486

487

488

489
Cushman JA. 1921. Foraminifera of the Philippine and adjacent seas. Bulletin of the United States National Museum 100, 4:1-608.

Cushman JA. 1924. Samoan Foraminifera. Publications of the Carnegie Institution of Washington, no. 342, Departement of Marine Biology Papers 21:1-85.

Cushman JA. 1932. The foraminifera of the tropical Pacific collections of the "Albatross", 1899-1900.

Part 1. Astrorhizidae to Trochamminidae. Bulletin of the United States National Museum 161:1-88.

Debenay J-P. 2012. A Guide to 1,000 Foraminifera from Southwestern Pacific, New Caledonia. Paris: Editions IRD Marseille/Publications Scientifiques du Muséum.

Delage Y, Hérouard E. 1896. Traité de Zoologie Concrète, Vol. 1, La Cellule et les Protozoaires. Paris: Schleicher Frères.

DeVantier L, Turak E, Allen G. 2009. Reef-scapes, reef habitats and coral communities of Raja Ampat, Birds's Head Seascape, Papua, Indonesia. Report to The Nature Conservancy, Bali, Indonesia.

DOI: 10.13140/RG.2.1.4668.5521.

Ehrenberg CG. 1839. Über die Bildung der Kreidefelsen und des Kreidemergels durch unsichtbare Organismen. Physikalische Abhandlungen der Königlichen Akademie der Wissenschaften zu Berlin, 1838 [1840: separate 1839]:59-147

Ekman S. 1953. Zoogeography of the Sea. London: Sidgwick and Jackson.

Erdmann MV, Pet JS. 2002. A rapid marine survey of the northern Raja Ampat Islands (Eastern Indonesia). Report from Henry Foundation/The Nature Conservancy/NRM/EPIQ, 36 pp, The Nature Conservancy. Available at http://www.rajaampat.org/downloads/Raja4\%20trip\%20report.pdf (accessed 24 February 2016)

Graham JJ, Militante PJ. 1959. Recent foraminifera from the Puerto Galera Area, northern Mindoro, Philippines. Stanford University Publications, Geological Sciences 6:1-171.

Haig DW. 1988a. Miliolid foraminifera from the inner neritic sand and mud facies of the Papuan Lagoon, New Guinea. Journal of Foraminiferal Research 18:203-236. DOI: 10.2113/gsjfr.18.3.203.

Haig DW. 1988b. Distribution of miliolid foraminifera in marine sediments around Motupore Island, Papua New Guinea. Science in New Guinea 14:54-94.

Haig DW. 1993. Buliminid foraminifera from inner neritic and mud facies of the Papuan Lagoon. Journal of Foraminiferal Research 23:162-179. DOI:10.2113/gsjfr.23.3.162.

Hatta A, Ujiié H. 1992. Benthic Foraminifera from Coral Seas between Ishigaki and Iriomote Islands, Southern Ryukyu Island Arc, Northwestern Pacific. Part 1. Systematic Descriptions of Textulariina and Miliolina. Bulletin of the College of Science, University of Ryukyus 53:49-119. 
490

491

492

493

494

495

496

497

498

499

500

501

502

503

504

505

506

507

508

509

510

511

512

513

514

515

516

517

518

519

520

521

522

523

524

525

526

527

528

529

530

531

532

533

534

535

536

537
Hoeksema BW. 2007. Delineation of the Indo-Malayan Centre of Maximum Marine Biodiversity: The Coral Triangle. In: W. Renema, ed. Biogeography, Time, and Place: Distributions, Barriers, and Islands, 117-178. DOI: 10.1007/978-1-4020-6374-9_5

Hofker J. 1927. The Foraminifera of the Siboga Expedition. Part 1. Families Tinoporidae, Rotaliidae, Nummulitidae, Amphisteginidae. Siboga Expeditie, Monographie IVa. Leiden. E.J. Brill:1-78.

Hofker J. 1930. The foraminifera of the Siboga Expedition. Part 2. Families Astorhizidae, Rhizamminidae, Reophacidae, Anomalinidae, Peneroplidae. Siboga Expeditie, Monographie IVa. Leiden. E.J. Brill:79-170.

Hohenegger J. 2004. Depth coenoclines and environmental considerations of Western Pacific larger foraminifera. Journal of Foraminiferal Research 34:9-33. DOI: 10.2113/0340009

Hohenegger J. 2011. Large Foraminifera - Greenhouse constructions and gardeners in the oceanic microcosm. Kagoshima, Japan: The Kagoshima University Museum.

Langer MR. 1992. New Recent foraminiferal genera and species from the lagoon at Madang, Papua New Guinea. Journal of Micropaleontology 11:85-93. DOI: 10.1144/jm.11.1.85.

Langer MR, Hottinger L. 2000. Biogeography of selected "larger" foraminifera. In: JJ Lee, ed. Biology of Foraminifera. Micropaleontology 46 Suppl. 1:105-126.

Langer MR, Lipps JH. 2003. Foraminiferal distribution and diversity, Madang Reef and Lagoon, Papua New Guinea. Coral Reefs 22:143-154. DOI: 10.1007/s00338-003-0298-1.

Langer MR, Thissen JM, Makled WA, Weinmann AE. 2013. The foraminifera from the Bazaruto Archipelago (Mozambique). Neues Jahrbuch für Geologie und Paläontologie. Abhandlungen Band 267/2:155-170. DOI: 10.1127/0077-7749/2013/0302.

Loeblich AR, Tappan H. 1987. Foraminiferal genera and their classification. New York: Van Nostrand Reinhold Company 1, 970 p., 2, 847 pls.

Loeblich AR, Tappan H. 1994. Foraminifera of the Sahul Shelf and Timor Sea. Cushman Foundation for Foraminiferal Research, Special Publication 31:1-661.

Makled WA, Langer MR. 2011. Benthic Foraminifera from the Chuuk Lagoon Atoll System (Caroline Islands, Pacific Ocean). Neues Jahrbuch für Geologie und Paläontologie. Abhandlungen Band 259:231249. DOI: 10.1127/0077-7749/2011/0119.

Mangubhai S, Erdmann MV, Wilson JR, Huffard CL, Ballamu F, Hidayat NI, Hitipeuw C, Lazuardi ME, Muhajir, Pada D, Purba G, Rotinsulu C, Rumetna L, Sumolang K, Wen W. 2012. Papuan Bird's Head Seascape: Emerging threats and challenges in the global center of marine biodiversity. Marine Pollution Bulletin 64:2279-2295. DOI: 10.1016/j.marpolbul.2012.07.024.

McCulloch I. 1977. Qualitative Observations on Recent Foraminiferal Tests with Emphasis on the Eastern Pacific: Parts I, II, III. Los Angeles: University of Southern California. 
538 McKenna S, Allen G, Suryadi S, eds. 2002. A Marine Rapid Assessment of the Raja Ampat Islands, Papua 539 Province, Indonesia. Conservation International, Washington DC: RAP Bulletin of Biological Assessment 540 22. Available at

541 http://www.conservation.org/publications/Documents/RAP_Reports/RAP22_Raja_Ampat_Indonesia_A

542 pr-2002.pdf (accessed 24 February 2016)

543

544

550

551

552

553

554

555

556

557

558

559

560

561

562

563

564

565

566

567

568

569

570

571

572

573

574

575

576

577

578

579

580

581

582

583

584

585
Millett FW. 1970. Report on the recent foraminifera of the Malay Archipelago collected by Mr. A. Durrand, F.R.M.S., Parts 1-17. Reprinted from Journal of the Royal Microscopical Society, 1898-1904. With a new introduction by J. Hofker. Lochem: Antiquariaat Junk.

Orbigny A. d' 1826. Tableau méthodique de la classe des Céphalopodes. Annales des Sciences Naturelles 7:245-314.

Orbigny A. d' 1839. Foraminifères. In: Ramon de la Sagra, ed. Histoire physique, politique et naturelle de l'île de Cuba. Paris: Arthus Bertrand:1-224.

Parker J. 2009. Taxonomy of Foraminifera from Ningaloo Reef, Western Australia. Memoirs of the Association of Australasian Paleontologists 36:1-810.

Prazeres M, Uthicke S, Pandolfi JM. 2016. Influence of local habitat on the physiological responses of large benthic foraminifera to temperature and nutrient stress. Scientific Reports 6, 21936. DOI: 10.1038/srep21936.

Renema W. 2003. Larger foraminifera on reefs around Bali (Indonesia). Zoologische Verhandelingen 345:337-366.

Renema W. 2006. Large benthic foraminifera from the deep photic zone of a mixed siliciclasticcarbonate shelf off East Kalimantan, Indonesia. Marine Micropaleontology 58:73-82.

DOI: 10.1016/j.marmicro.2005.10.004.

Renema W. 2010. Is increased calcarinid (foraminifera) abundance indicating a larger role for macroalgae in Indonesian Plio-Pleistocene coral reefs? Coral Reefs 29:165-173. DOI: 10.1007/s00338-0090568-7.

Renema W, Troelstra SR. 2001. Larger foraminifera distribution on a mesotrophic carbonate shelf in SW Sulawesi (Indonesia). Palaeogeography, Palaeoclimatology, Palaeoecology 175:125-147.

DOI: 10.1016/S0031-0182(01)00389-3.

Renema W, Hohenegger J. 2005. On the identity of Calcarina spengleri (Gmelin, 1791). Journal of Foraminiferal Research 35:15-21. DOI: 10.2113/35.1.15.

Reuss AE. 1851. Ueber die fossilen Foraminiferen und Entomostraceen der Septarienthone der Umgegend von Berlin. Berlin: Zeitschrift der Deutschen Geologischen Gesellschaft 3:49-91.

Roberts CM, McClean CJ, Veron JEN, Hawkins JP, Allen GR, McAllister DE, Mittermeier CG, Schueler FW, Spalding M, Wells F, Vynne C, Werner TB. 2002. Marine Biodiversity Hotspots and Conservation Priorities for Tropical Reefs. Science 295:1280-1284. DOI: 10.1126/science.1067728. 
586
Saidova KM. 1975. Bentosnye Foraminifery Tikhogo Okeana [Benthonic foraminifera of the Pacific Ocean], 3 vol. Moscow: Institut Okeanologii P. P. Shirshova, Akademiya Nauk SSSR.

Saidova KM. 1981. O sovremennom sostoyanii sistemy nadvidovykh taksonov Kaynozoyskikh bentosnykh foraminifer [On an up-to-date system of supraspecific taxonomy of Cenozoic benthonic foraminifera]. Moscow: Institut Okeanologii P. P. Shirshova, Akademiya Nauk SSSR.

Schultze MS. 1854. Über den Organismus der Polythalamien (Foraminiferen), nebst Bemerkungen über die Rhizopoden im Allgemeinen. Leipzig: Wilhelm Engelmann.

Schwager C. 1876. Saggio di una classificazione dei foraminiferi avuto riguardo alle loro famiglie naturali. Bolletino R. Comitato Geologico d'Italia 7:475-485.

Tittensor DP, Mora C, Jetz W, Lotze HK, Ricard D, Vanden Berge E, Worm B. 2010. Global patterns and predictors of marine biodiversity across taxa. Nature 466:1098-1011. DOI: 10.1038/nature09329.

Turak E, Souhoka J. 2003. Coral Diversity and the Status of Coral Reefs in the Raja Ampat Islands. In: R., Donnelly, D. Neville \& P. Mous, eds. Report on a rapid ecological assessment of the Raja Ampat Islands, Papua, Eastern Indonesia, held October 30 - November 22, 2002. The Nature Conservancy Southeast Asia Center for Marine Protected Areas, Sanur, Bali Indonesia. Available at http://www.rajaampat.org/downloads/RajaAmpatREAFinalDraft\%20Screen.pdf (accessed 24 February 2016)

Vella P. 1957. Studies in New Zealand foraminifera. Paleontological Bulletin, Wellington 28:1-64.

Veron JEN. 1995. Corals in space and time: the biogeography and evolution of the Scleractinia. Ithaca, New York: Cornell University Press.

Veron JEN, DeVantier LM, Turak E, Green AL, Kininmonth S, Stafford-Smith M, Peterson N. 2009.

Delineating the Coral Triangle. Galaxea, Journal of Coral Reef Studies 11:91-100.

DOI: 10.3755/galaxea.11.91

Weinmann AE, Rödder D, Lötters S, Langer MR. 2013. Heading for New Shores: Projecting Marine Distribution Ranges of Selected Larger Foraminifera. PLOS ONE 8(4): DOI:10.1371/journal.pone.0062182

Wiesner H. 1923. Die Milioliden der östlichen Adria. Prag-Bubenec.

Wiesner H. 1931. Die Foraminiferen der deutschen Südpolar Expedition 1901-1903. Deutsche Südpolarexpedition, vol. 20, Zoologie 12:53-165. 
1

Maps of the sampling area.

(A) Area of the Coral Triangle (shaded) in the Central Indo-Pacific; (B) location of Raja Ampat northwest of the Bird's Head Peninsula (West Papua, Indonesia); (C) location of sample stations where the species described herein occur (for details see Tbl. 1).

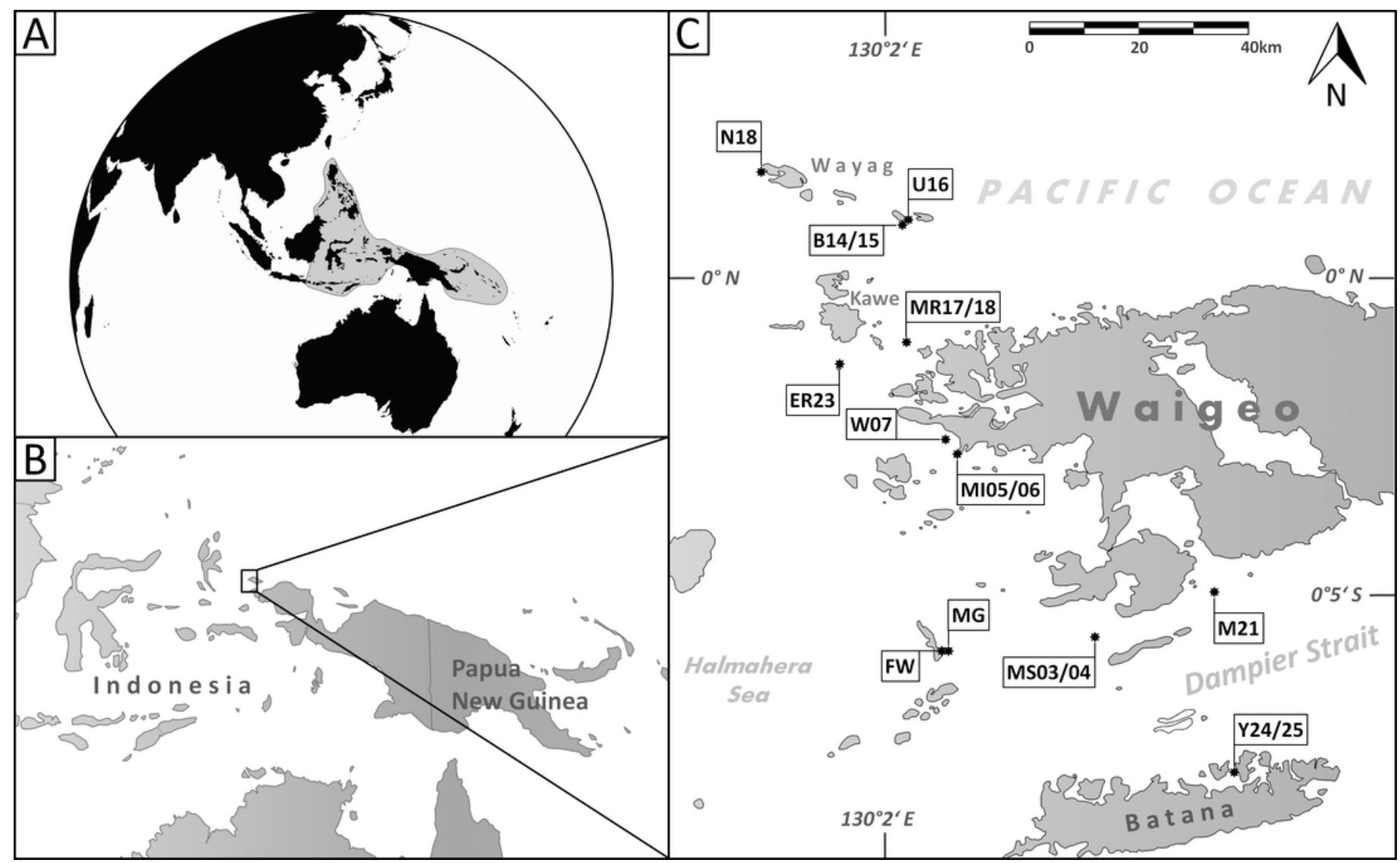




\section{2}

Holotype, paratype, CT scans and details of Dentoplanispirinella gen. nov. occulta sp. nov.

(A) Side view and (B) apertural view of a more juvenile specimen with a nearly triangular aperture and weakly developed tooth (paratype); (C) side view and (D) apertural view (holotype); (E) apertural view of a specimen with a well-developed tooth and elongated aperture; (F) detail of a well-developed peripheral keel; (G) CT scan reconstruction of the chamber cavities revealing the presence of 2.5 to 3.5 chambers per whorl in an adult specimen (note that penultimate chamber is broken); $(\mathrm{H}) \mathrm{CT}$ scan showing planispirally arranged chambers; (I) detail of an aperture with a very well-developed tooth; (J) detail of the striate surface ornamentation; $(\mathrm{K})$ detail of the construction of the outer wall layer showing randomly arranged calcite needles in the lower part (test surface removed) and longitudinally arranged calcite needles on the outer test surface. Scale bar is $100 \mu \mathrm{m}$ (unless indicated). 


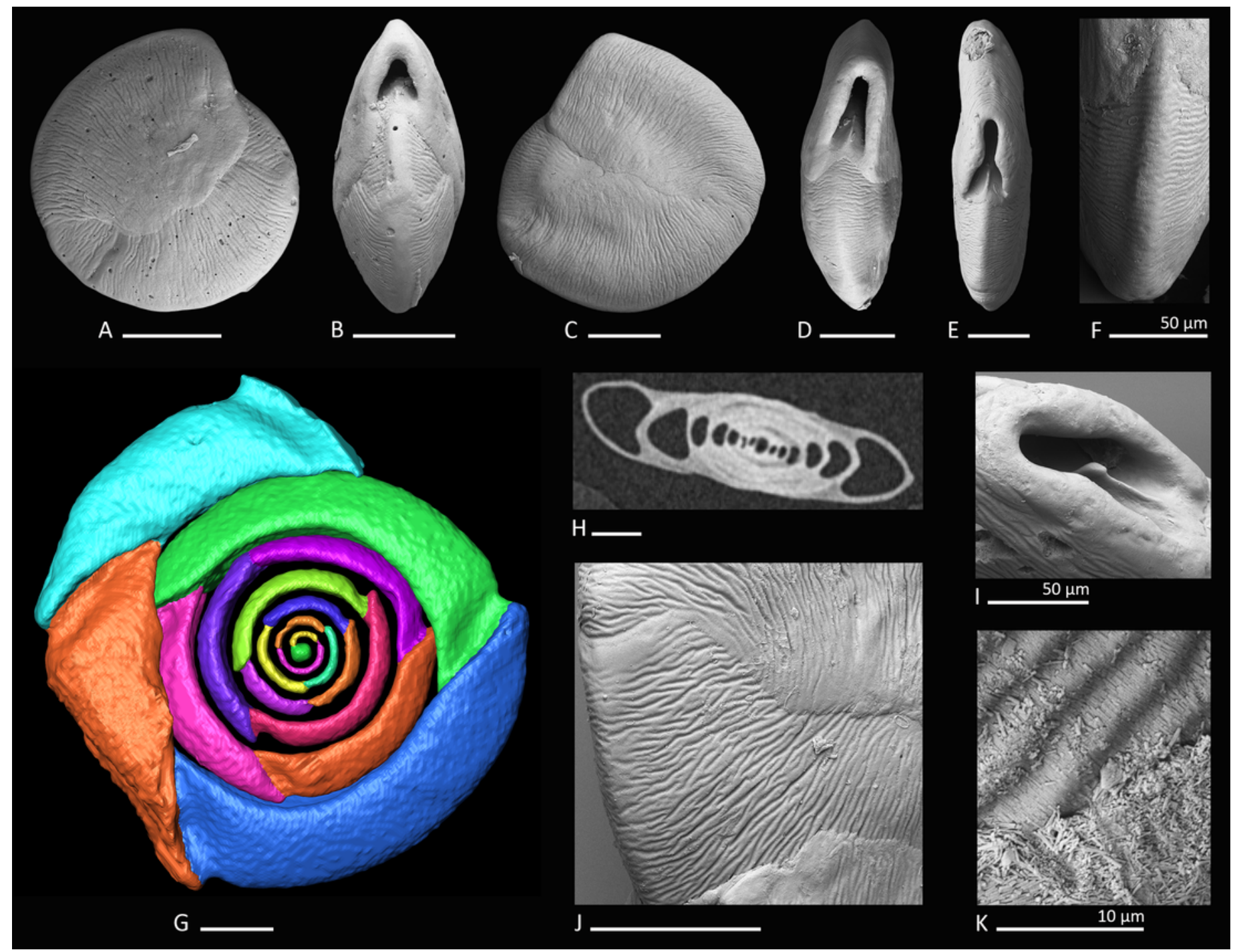


3

Holotype and paratypes of Miliolinella moia sp. nov.

(A-C) Holotype, five chambers visible from the exterior: (A) lateral view of more evolute side; (B) top view; (C) lateral view of more involute side; (D-F) paratype, a specimen with a broken ultimate chamber showing three chambers visible from the exterior: (D) lateral view of more evolute side; (E) top view; (F) lateral view of more involute side; (G-I) a specimen with four chambers visible from the exterior: $(\mathrm{G})$ lateral view of more evolute side; $(\mathrm{H})$ top view; (I) lateral view of more involute side; (J-L) a specimen with four chambers visible from the exterior: (J) lateral view of more involute side; (K) top view; (L) lateral view of more evolute side. Scale bar is $100 \mu \mathrm{m}$.

*Note: Auto Gamma Correction was used for the image. This only affects the reviewing manuscript. See original source image if needed for review. 


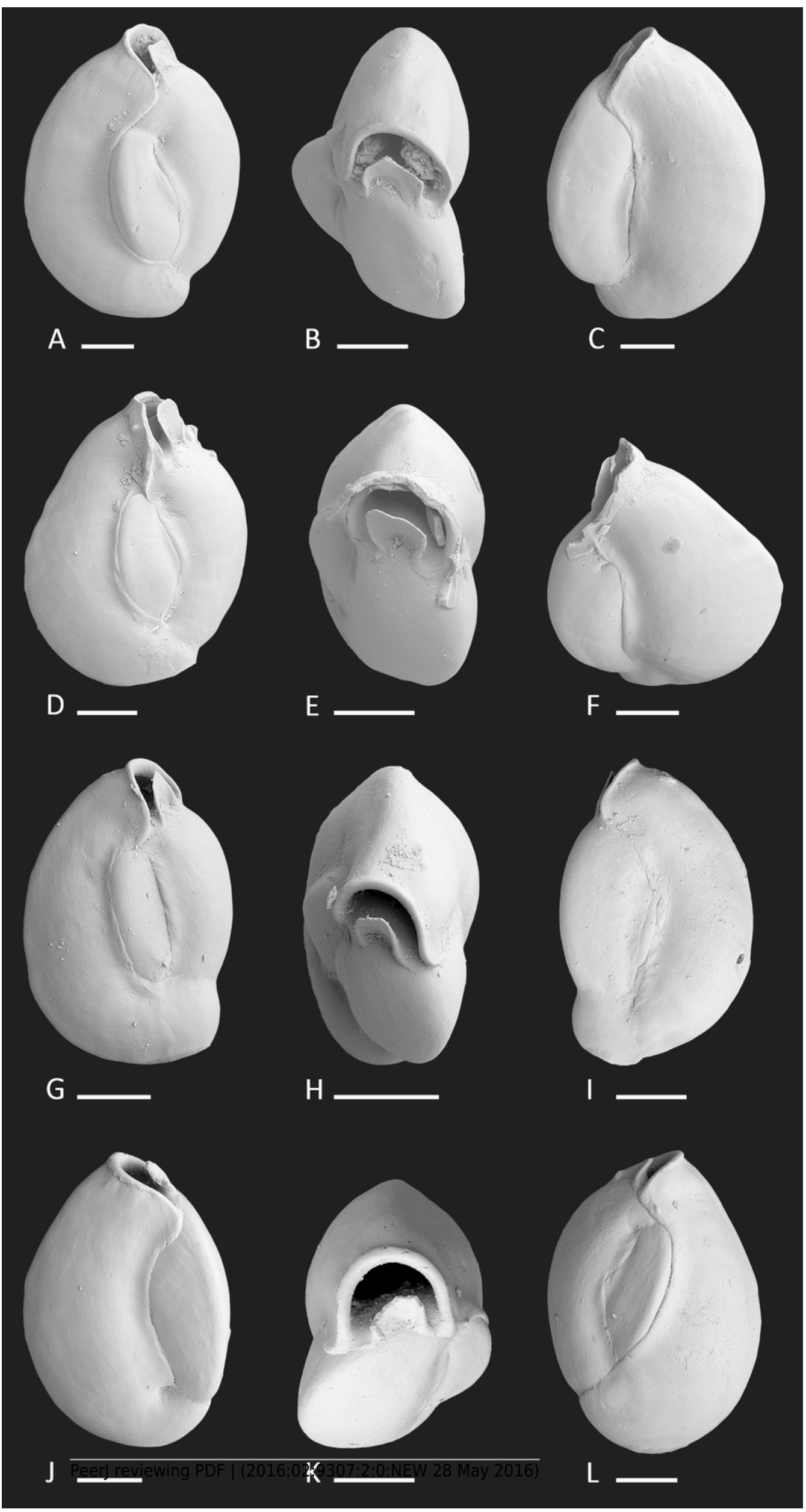




\section{4}

Holotype and paratypes of Miliolinella undina sp. nov.

(A-C) Holotype: (A) oblique apertural view; (B) apertural view; (C) lateral view of more involute side; (D-F) a specimen with the final chamber missing: (D) lateral view of more evolute side; (E) top view; (F) lateral view of more involute side; (G - I) a specimen with an erratic growth stage in the final chambers: $(\mathrm{G})$ side view; $(\mathrm{H})$ top view; (I) lateral view of more involute side. Scale bar is $50 \mu \mathrm{m}$.

*Note: Auto Gamma Correction was used for the image. This only affects the reviewing manuscript. See original source image if needed for review. 


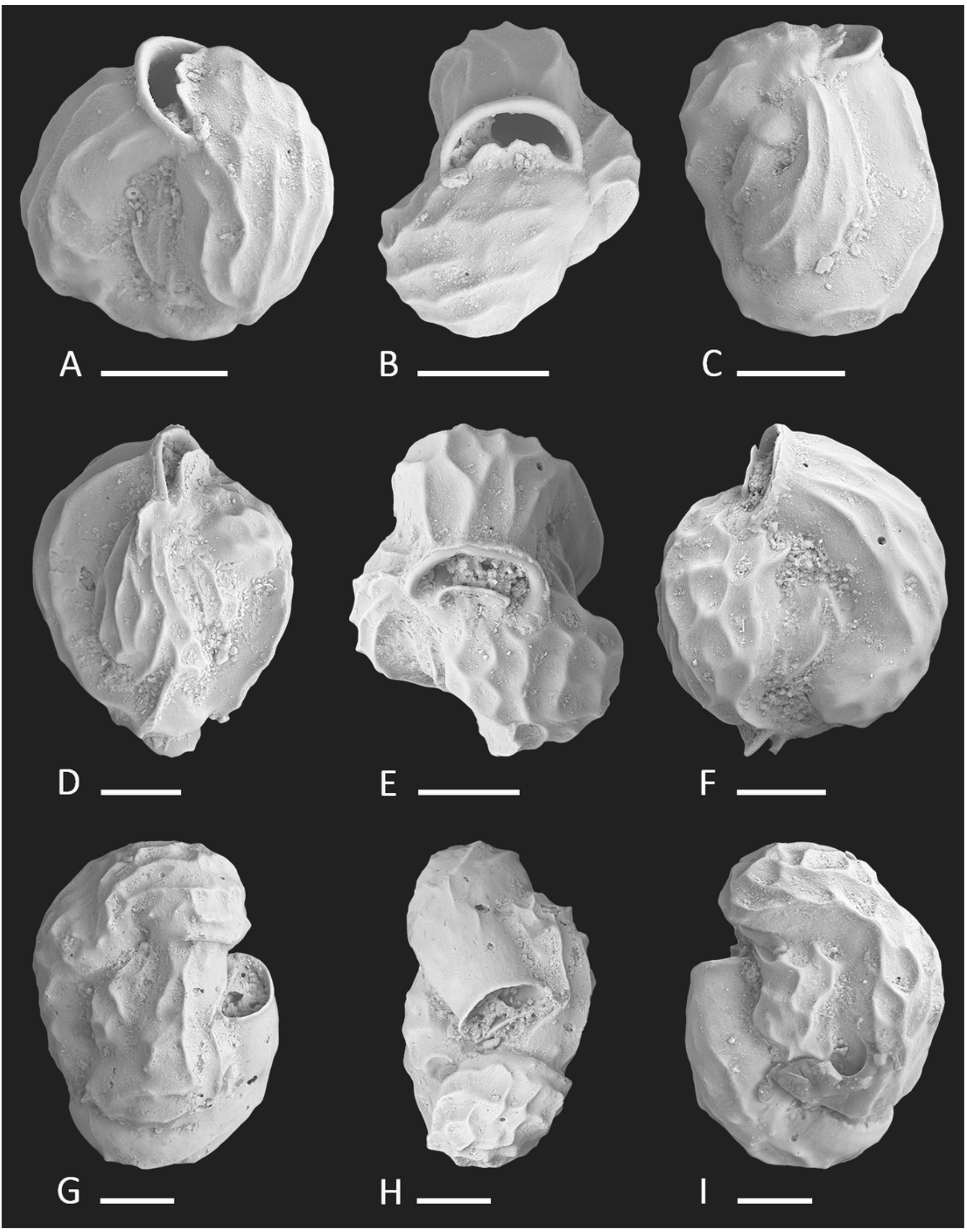




\section{5}

Holotype, paratype, cross section and detail of Triloculina kawea sp. nov.

(A-C) Holotype: (A) lateral view of more involute side; (B) apertural view; (C) lateral view of more evolute side; (D) cross section of a specimen; (E-G) Paratype: (E) lateral view of more evolute side; $(F)$ apertural view; $(G)$ lateral view of more involute side; $(H)$ detail of the irregular test surface. Scale bar is $100 \mu \mathrm{m}$ (unless indicated).

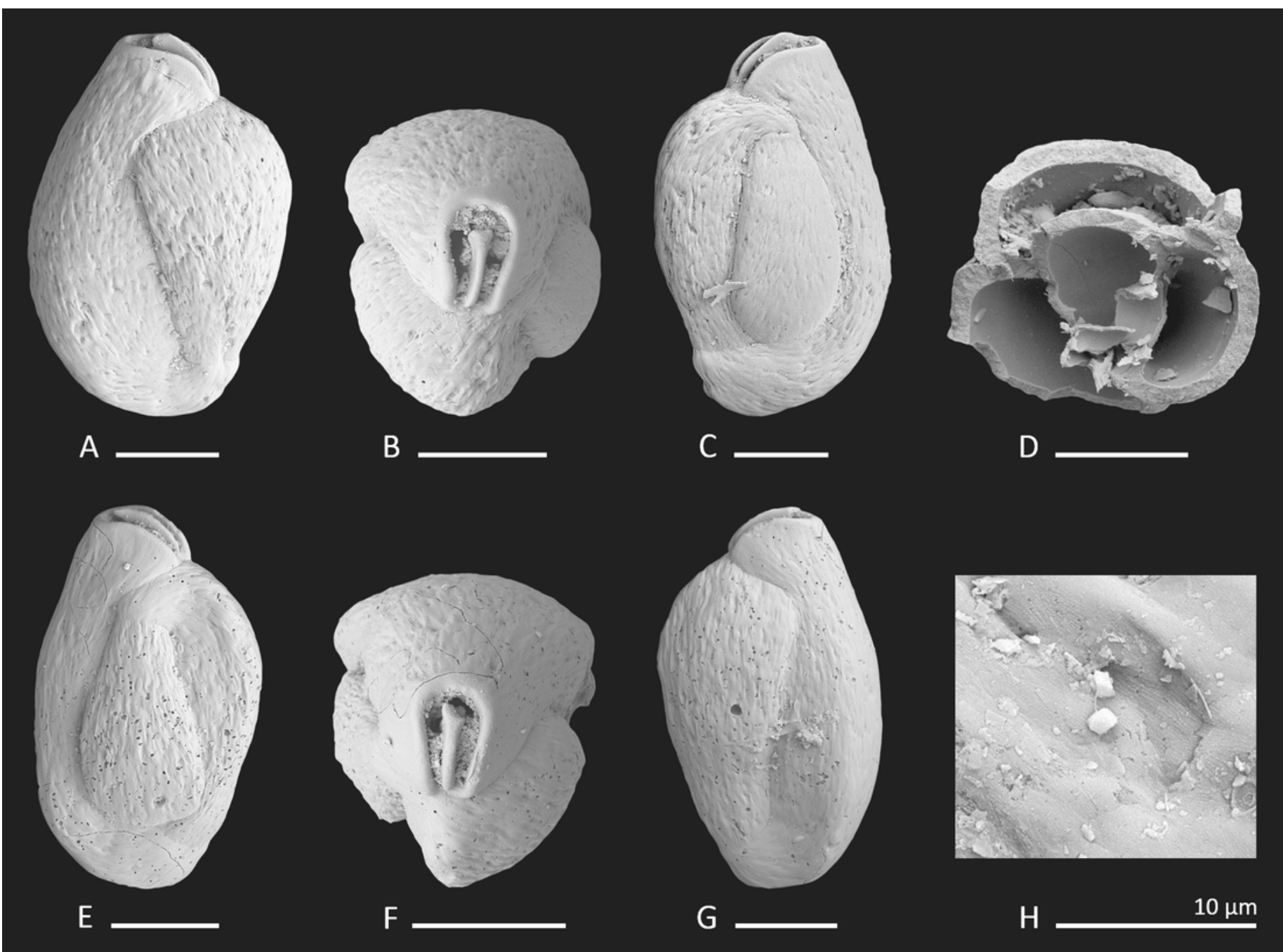


6

Holotype and paratype of Siphonaperta hallocki sp. nov.

(A-C) Holotype: (A) lateral view of more evolute side; (B) apertural view; (C) lateral view of more involute side; (D-F) paratype: (D) lateral view of more evolute side; $(E)$ apertural view; (F) lateral view of more involute side. Scale bar is $100 \mu \mathrm{m}$ (unless indicated).

*Note: Auto Gamma Correction was used for the image. This only affects the reviewing manuscript. See original source image if needed for review. 


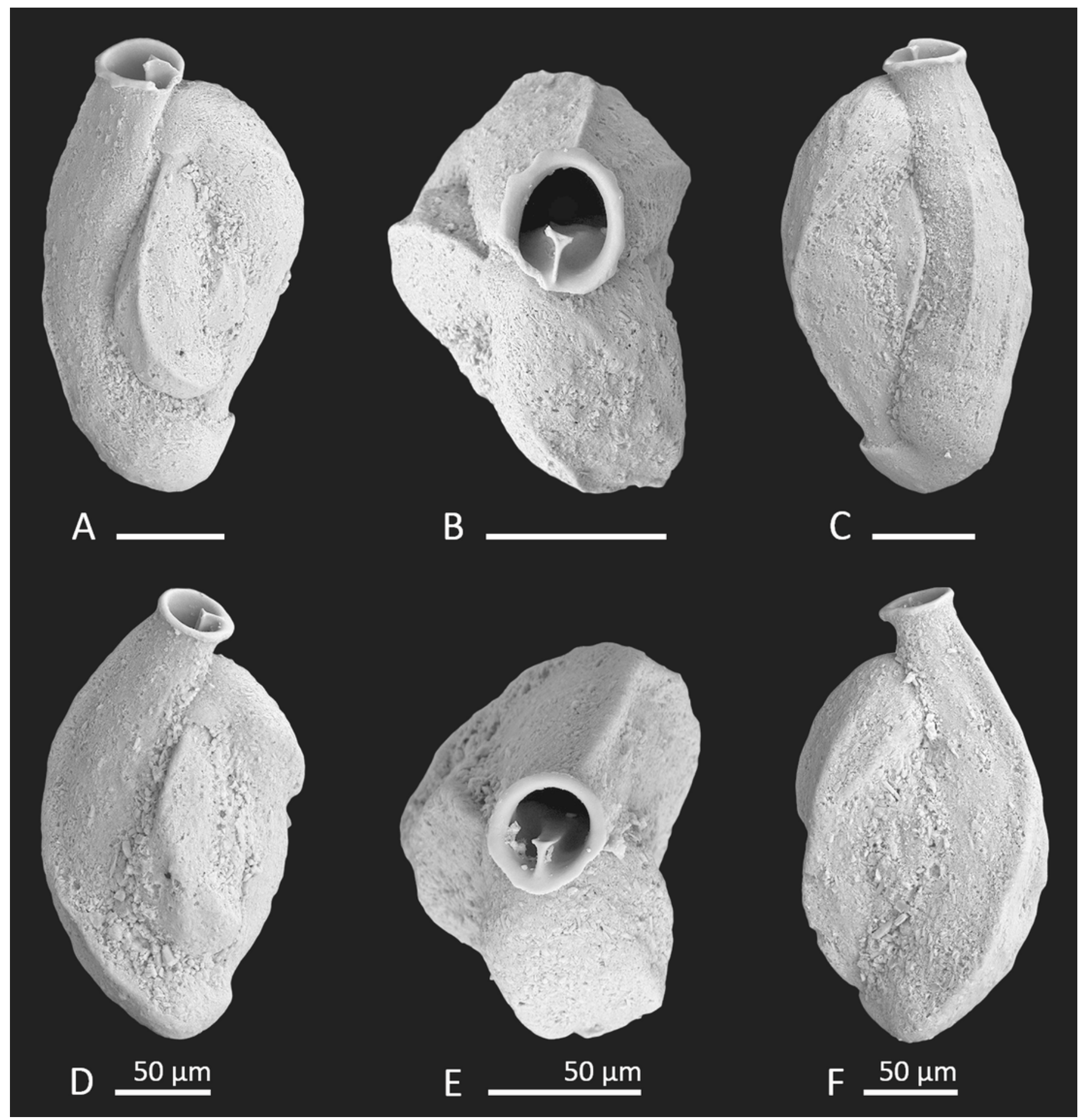




\section{Table $\mathbf{1}$ (on next page)}

Collection sites

Sample site information for collection locations from Raja Ampat (Indonesia) including environmental information on reefal habitat type. 


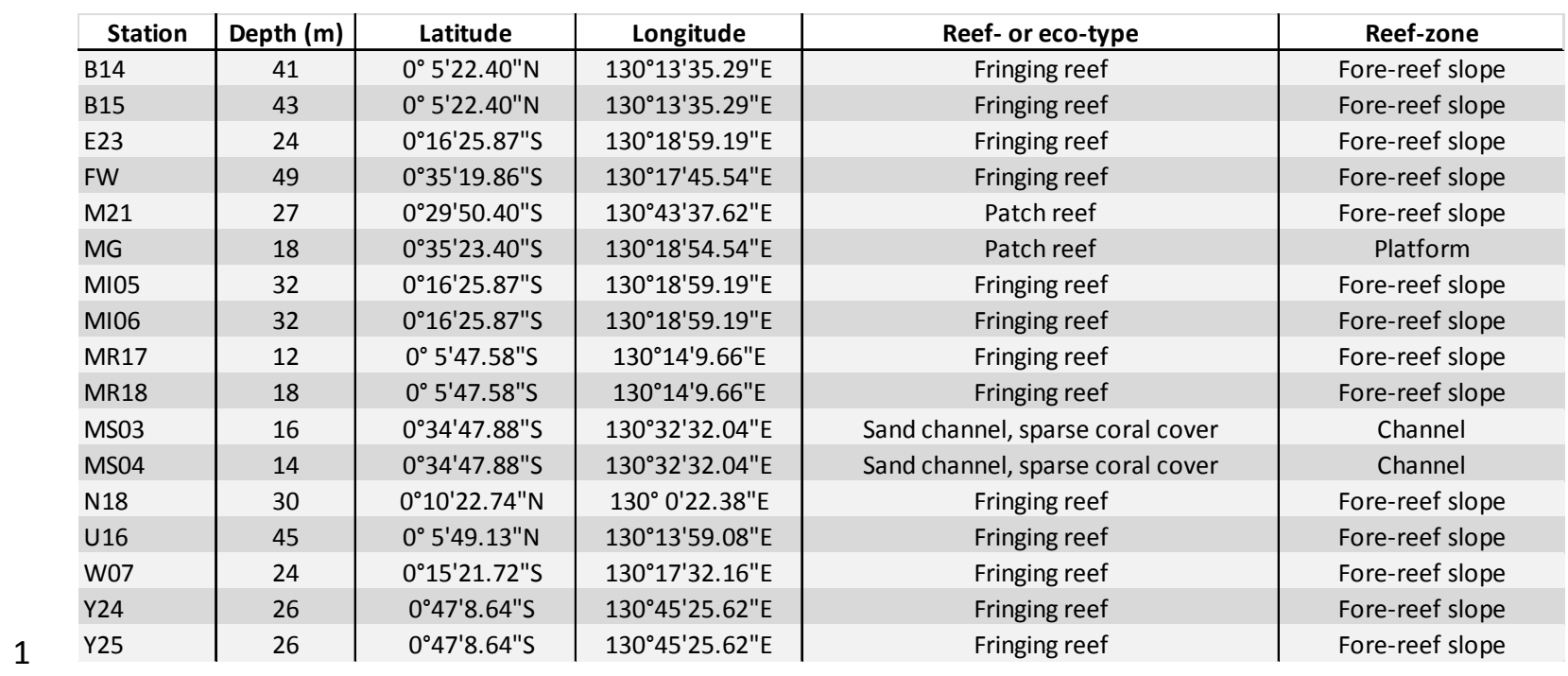

